\title{
Firm growth in the course of mergers and acquisitions
}

\author{
Dirk Burghardt $\cdot$ Marco Helm
}

Accepted: 17 December 2014/Published online: 13 February 2015

(C) Springer Science+Business Media New York 2015

\begin{abstract}
This paper examines the effect of mergers and acquisitions on employment growth in newly acquired firm establishments. Based on a unique full sample of manufacturing and services firms in Switzerland, our main finding is that the relative size of a deal is an important growth determinant: While the initial size of the acquiring firm is positively related to an acquired establishment's growth, the opposite holds true for the initial size of the acquisition. We also contribute to a controversial debate on firm growth in general by rejecting Gibrat's law of proportionate growth for firm establishments in Switzerland. In fact, employment growth decreases with an establishment's initial size and age — at the aggregate level as well as within separate subsamples of manufacturing and services firms.
\end{abstract}

Disclaimer: All views contained in this paper are solely those of the authors and cannot be attributed to the Swiss Competition Commission or its Secretariat.

D. Burghardt $(\bowtie)$

Department of Economics, University of St. Gallen, Varnbüelstrasse 19, 9000 St. Gallen, Switzerland e-mail: dirk.burghardt@unisg.ch

\section{Helm}

Secretariat of the Swiss Competition Commission, Monbijoustrasse 43, 3003 Bern, Switzerland

e-mail: marco.helm@weko.admin.ch
Keywords Firm growth · Employment - Gibrat's law · Mergers and acquisitions - Deal size · Establishment-level data $\cdot$ Switzerland

JEL Classifications: G34 - L11 $\cdot$ L25 $\cdot$ M51 · L26

\section{Introduction}

What determines the growth of firms and their establishments ${ }^{1}$ Do small establishments grow more rapidly than large ones? And how is an establishment's growth affected by mergers and acquisitions? The empirical analysis of firm growth-often measured in terms of employment-has received considerable attention since the formulation of Gibrat's law of proportionate growth, stating that the growth of a firm is uncorrelated with its initial size (Gibrat 1931; Sutton 1997). However, the jury is still out. While most recent studies tend to reject Gibrat's law, others accept it as appropriate depending on, for example, the sector of activity (Audretsch et al. 2004; Daunfeldt and Elert 2013). Even less is known about how mergers and acquisitions affect employment growth in

\footnotetext{
${ }^{1}$ By "establishment," this study refers to a building or building complex of a firm which can either be a single-establishment firm, the headquarters of a multi-establishment firm, or be a companion establishment of a multi-establishment firm. A manufacturing establishment may also be referred to as "plant".
} 
newly acquired establishments. Does growth decrease following a merger such that efficiency gains from cutting overlapping functions are realized? Or does growth actually increase such that a firm's expansion is reinforced? Surprisingly, while the size of firms and establishments plays a central role in the general literature on firm growth, it has been disregarded as a potential determinant in the literature that analyzes the employment effects of mergers and acquisitions. Neither the size of the acquiring firm nor the size of the acquired target establishments has been taken into account so far.

This paper uses the Swiss Business Census ("BFS Betriebszählung") to study firm growth in the course of mergers and acquisitions. The Swiss Business Census is a unique full sample of all firms and firm establishments registered in Switzerland. Collected by the Swiss Federal Statistical Office ["Bundesamt für Statistik (BFS)"], the data allow us to track individual firm establishments and their characteristics from 2001 to 2005. Out of about 348,000 establishments that constitute the Swiss services and manufacturing sector in the year 2001, we identify 5,389 establishments that were acquired by another firm within the subsequent four years. These numbers also include very small establishments, which are often disregarded by other studies due to the lack of data availability. In fact, the full sample property of our data set makes this study to a study of small businesses: measured in 2001, more than $86 \%$ of all establishments in Switzerland have less than 10 employees and more than $97 \%$ of all establishments have less than 50 employees. $^{2}$

Our empirical model relates an establishment's employment growth between 2001 and 2005 to a number of explanatory variables. At first, variables are included, which have been identified as potential general growth determinants by the literature, such as the initial size or age of the establishment. We then investigate how the status of being "recently acquired" influences growth outcomes. To cope with endogeneity concerns, in a robustness check we

\footnotetext{
${ }^{2}$ The Swiss Federal Statistical Office defines four size groups for firms in Switzerland. Micro-firms are defined as having 0-9 employees, small firms have 10-49, medium firms have 50-249, and large firms have 250 or more employees. For convenience, the same thresholds are applied to characterize establishments here.
}

employ the idea that among multi-establishment mergers-where not just one but several different establishments are acquired at the same time-the acquisition of an individual establishment can be treated as exogenous.

Among a number of findings, three results stand out. First, we find that establishment growth decreases with an establishment's initial size and age. We can thus reject Gibrat's law of proportionate growth, stating that growth is uncorrelated with initial size. This result holds at the aggregate level as well as when manufacturing and services sectors are evaluated separately. The following sections will show how this contributes to an ongoing discussion on the growth of firms and firm establishments in general. Second, turning to the analysis of mergers and acquisitions, we find that the size of the acquiring firm is positively related to the growth of a newly acquired establishment. Third, the combined size of the newly acquired establishments is negatively related to its growth. In other words, the relative size of a deal is an important determinant for the internal growth of a newly acquired establishment's workforce. This finding is new to the literature and the following sections will provide a number of possible explanations.

The remainder of this paper is structured as follows. Section 2 presents some theoretical considerations and a brief review of the two strands of the literature this study contributes to. Section 3 describes our data. Section 4 introduces the empirical model. Section 5 provides our regression results and their discussion. Section 6 presents some further robustness checks. Section 7 concludes and suggests directions for future research.

\section{Related literature}

This paper is related to two strands of the literature. First, this paper contributes to an ongoing discussion on the growth patterns of firms and firm establishments in general. The debate may have started with the formulation of Gibrat's law of proportionate growth. Gibrat (1931) stated that the growth of a firm or of an establishment is uncorrelated with its initial size. This (non-existing) relationship between initial size and growth was intended to be helpful for the mathematical modeling of firm dynamics. Indeed, Gibrat (1931) found it to be empirically true for his data on French 
manufacturing establishments in 1920 and 1921. Other early studies accept his findings, at least as a first approximation (see Sutton 1997 for a survey). Later studies, by contrast, tend to reject Gibrat's law and find an inverse relationship between growth and size or age—at the firm level (Hall 1987; Evans 1987a, b; Dunne and Hughes 1994; Harhoff et al. 1998) as well as at the level of individual establishments (Dunne et al. 1989; Blonigen and Tomlin 2001). ${ }^{3}$ An explanation for this inverse relationship is the theory of learning over time, as proposed by Jovanovic (1982). Notably, most of these studies are based on aggregate samples of manufacturing firms.

Recent studies on firm growth qualify these insights by evaluating new (sub)samples of firms. Between groups of small and large firms, young and old firms, and firms of different sectors, differing effects of size and age on growth are observed. Geroski and Gugler (2004), for example, confirm an inverse size-growth relationship for small and young manufacturing firms, but find Gibrat's law to hold for large and mature manufacturing firms. Further studies reach similar conclusions (Lotti et al. 2003; Fotopoulos and Giotopoulos 2010; Nunes et al. 2013). A study by Audretsch et al. (2004) raises the question whether services firms are systematically different to manufacturing firms. In contrast to most related manufacturing studies, the authors indeed find Gibrat's law to hold in number of small-scale hospitality industries. Also other studies emphasize that there may be fundamental sectoral differences (Teruel-Carrizosa 2010; Daunfeldt and Elert 2013). An explanation which is in line with these findings is that young and small firms have a higher pressure to grow until they reach a minimum efficient scale that allows them to survive in the market. Furthermore, the threshold for such a minimum efficient scale may be much lower in a typical services industry than in the manufacturing sector (e.g., TeruelCarrizosa 2010).

In addition to size, age, and sector of activity, it should be noted that the literature explores a number of further potential growth determinants. These include financial constraints (Carpenter and Petersen 2002;

\footnotetext{
${ }^{3}$ Note that total firm growth can be decomposed into internal establishment growth and external growth through the acquisition of additional establishments. Thus, the results for aggregate internal establishment growth are not necessarily equivalent to total firm growth.
}

Oliviera and Fortunato 2006), location (Hoogstra and van Dijk 2003; Reid and Xu 2012), sales uncertainty (Lensink et al. 2005), the use of external business advice (Robson and Bennett 2000), and technology intensity (Almus and Nerlinger 2000; Yasuda 2005).

A second strand of the literature this paper contributes to is the analysis of the effects of mergers and acquisitions on (employment) growth. So far, a coherent theory that would predict such effects does not exist. The reason might be that it is indeed difficult to capture all relevant mechanisms within a single theoretical model. Individual mergers take place for different motives, implying also different effects on employment. A study by Andrade et al. (2001) classifies the possible reasons for mergers and acquisitions into five categories: (1) efficiency-related reasons, (2) the creation of market power, (3) market discipline, (4) agency costs, and (5) opportunities for diversification. Suppose, for example, a merger takes place for efficiency-related reasons. Typically, this implies that there exist overlapping job functions that can be cut. In the course of the merger, employment then gets reduced in order to realize the intended efficiency gains. Suppose, by contrast, two businesses merge because of the empire-building tendencies of their managers as a particular form of agency costs. The managers are then interested in hiring even more employees for the newly acquired establishment. Suppose, as a third example, firms use mergers as a vehicle to diversify their range of products. In an extreme case of very different products, there are no overlapping job functions that could be cut. For such mergers, we would expect that employment does not change at all.

Previous empirical studies indeed provide a mixed picture concerning the overall effect of mergers and acquisitions on employment. A number of studies find negative effects of corporate takeovers on employment. Conyon et al. (2002) suggest that firms in the UK reduce joint output as well as their overall use of labor after a merger. For related firms and hostile mergers, these effects are found to be particularly strong. Gugler and Yurtoglu (2004) find no significant effect for firms in the USA, but negative effects for firms in Europe. They attribute this difference to more rigid labor markets in Europe. Also a study by Bhagat et al. (1990) falls into the group of studies which find negative employment effects of corporate takeovers. In addition, they observe that white-collar employees 
are disproportionately affected by layoffs, many of them due to consolidations of headquarters. In a similar manner, Lichtenberg and Siegel (1990) differentiate between production establishments and auxiliary establishments where top managers, administrators, and R\&D personnel are employed. According to their study, ownership changes lead to a much lower employment growth in auxiliary establishments compared with production establishments.

Mixed effects depending on the type of acquisition are found in a sample of US manufacturing firms in the state of Michigan by Brown and Medoff (1988). They define three types of acquisition: asset-only sales, where ownership changes take place without integration with another firm; simple sales, where firms acquire assets of other firms without absorbing the workforce; and mergers, where most workers of the acquired firm are absorbed or combined with those of the acquirer. For firms that are part of simple sales or mergers, they find that employment decreases. For firms that are part of asset-only sales, they find the opposite.

A number of other studies tend to find positive effects of acquisitions on employment. According to an early study by Green and Cromley (1982), employment increases in the period following a horizontal merger. Using plant-level data for the US manufacturing sector, McGuckin and Nguyen (2001) find positive overall effects of changes in ownership on jobs and wages as well. However, this finding does not hold for the group of larger plants where ownership changes are actually associated with job losses. Furthermore, acquired plants are found to have a smaller probability of closing.

Overall, both strands of the literature are still of explorative nature and provide ample room for further research. This paper contributes to our understanding of a firm's growth determinants by analyzing a new data set which includes all firm establishments in Switzerland. In view of the first strand of the literature, it becomes clear that the initial size and age of an establishment should be taken into consideration as potential growth determinants in our analysis. It also seems reasonable to analyze manufacturing and services firms separately. On the one hand, given the enormous share of small firms and establishments among the Swiss economy, we could hypothesize that Gibrat's law will be rejected. On the other hand, it might still hold in the services sector if the minimum- efficient-scale firms' need to reach is small enough. While the size of firms and establishments plays a central role in the general literature on firm growth, it is surprising that it has been disregarded in the second strand of the literature above. We should thus pay attention to the role of firm size in the course of mergers and acquisitions. In particular, the size of the acquiring firm and the size of the acquired target establishments in a merger should be taken into account when evaluating related changes in employment growth.

\section{Data}

\subsection{Data source}

Our analysis is based on the Swiss Business Census ("BFS Betriebszählung"), a high-quality survey including all firms and firm establishments operating in the secondary and tertiary sector in Switzerland. The data are collected by the Swiss Federal Statistical Office ["Bundesamt für Statistik (BFS)"], with support from regional statistical offices. Collection takes place every three to four years via paper questionnaires, online questionnaires, or profiling methods such as interviews. Participation is mandatory for all firms in Switzerland. Among other variables, the survey captures the location, the sector of economic activity, and the number of employees of individual establishments. The Business Census is an important reference statistic for Switzerland that serves as a basis for various official reports on structural changes in the economy. It is also used for guiding political measures concerning, for example, regional development and planning. ${ }^{4}$ For this paper, we have data for the census years 2001 and 2005 available.

Each establishment observation in the Business Census is associated with a unique 9-digit identification number by the Swiss Federal Statistical Office (in German denoted as "Betriebs- und Unternehmensregister-Nummer"). In addition, it is associated with a separate 9-digit identification number for the firm it belongs to. The firm number is not unique in a sense

\footnotetext{
${ }^{4}$ See Swiss Federal Statistical Office (2006) for further information on the Business Census, including information on methods, its legal basis, and its usage. Also, a sample questionnaire is provided.
} 
that several establishments may belong to the same parent firm and thus have the same firm number. Apart from these identification numbers, the data are confidential and do not provide the firms' names. Identification numbers are consistent across sectors and regions, and they are stable over the census years under consideration. We can thus track individual firms and establishments from 2001 to 2005.

Based on this data structure, the growth rate of an establishment in terms of its number of employees can be calculated. Furthermore, an acquisition can be identified by the change of the firm number of an individual establishment between the years 2001 and 2005. In order to exclude simple ownership changes, where an establishment does not get integrated into a new institutional unit, we additionally require a resulting firm to consist of at least two establishments in 2005 .

\subsection{Variables and descriptive statistics}

In this section, we describe the variables in our data set and provide a first impression on what kind of acquisitions this study is based. As in the regression analysis that follows later, only establishments surviving from 2001 to 2005 are considered here, where corresponding growth rates can be calculated. In total, there are 262,032 such firm establishments in Switzerland. Table 1 presents summary statistics for all major variables. While panel I of Table 1 shows these statistics for all establishments in our data set, panel II shows them for the subsample of acquired establishments only. Following our definition of an acquisition from above, for establishments acquired between 2001 and 2005 we set the dummy variable $A$ equal to 1 , while it is set to zero otherwise.

Size 2001 denotes the size of an establishment in 2001, measured by its number of full-time equivalent employees. Size 2005 denotes the size of an establishment in 2005. As shown in panel I of Table 1, the size of establishments in 2001 ranges from 0.27 to about 5,333 full-time equivalent employees, with 8.80 being the average. Values for the year 2005 look similar. As shown in panel II, a total of 5,389 establishments got acquired between 2001 and 2005. Among acquired establishments, the size in 2001 ranges from 0.27 to about 1,542 full-time equivalent employees. In 2005 it ranges from 0.27 to about 862 . Although maximum values are thus lower for acquired establishments, acquired establishments are larger on average, with 21.75 full-time equivalent employees being the average for 2001 and 18.52 being the average for 2005 .

There are three Age dummies, which are constructed as follows: Age 4 equals 1 if an establishment began operation between October 1998 and September 2001, that is, if it had been in existence from 4 to 7 years by 2005. Age 7 equals 1 if an establishment began operation between October 1995 and September 1998, that is, if it had been in existence from 7 to 10 years by 2005. Age10 equals 1 if an establishment began operation before October 1995, that is, if it had been in existence for 10 years or more by 2005 . Otherwise the dummy equals zero. In order to find out an establishment's age, we check the existence of an establishment in surveys from 1995 and 1998 (due to changes in the coding system of firm numbers, we could not use these survey years for other parts of the analysis). Among all establishments, $18 \%$ fall into the youngest age group, $13 \%$ into the middle group, and $69 \%$ into the oldest age group. Among acquired establishments, the corresponding distribution looks very similar.

$H Q$ is a dummy which catches the headquarters status of an establishment in 2001. It equals 1 if an establishment is a single-establishment firm or the headquarters of a multi-establishment firm, and zero otherwise. Foreign Capital is a dummy which equals 1 if an establishment is (at least partly) owned by foreign capital in 2001, and zero if not (or if foreign ownership is unknown, as in some cases). Finally, Export Industry is a dummy which equals 1 if an establishment belongs to an industry in which an above-average share of firms exports in 2001, and zero otherwise. Among all establishments, $89 \%$ are headquarters, $2 \%$ are owned by foreign capital, and $63 \%$ operate in an exportoriented industry, following these definitions. Among acquired establishments, only $34 \%$ are headquarters, but $4 \%$ are owned by foreign capital and $71 \%$ operate in an export-oriented industry.

There are three variables that are only available for the group of acquired establishments. Integration Size denotes the sum of the number of employees (in fulltime equivalents) in 2001 of all establishments the acquirer of an establishment acquired between 2001 and 2005. It ranges from 0.27 to $13,888.08$ full-time equivalent employees, with $3,789.35$ being the average. Acquirer Size is the total number of employees (in full-time equivalents) of the acquiring firm of an 
Table 1 Summary statistics for major variables

As in the following regression analysis, only establishments that survive from 2001 to 2005 are considered. In addition to all establishments, values for the subsample of acquired establishments $(A=1)$ are presented. Missing values for Acquirer Size and Related Industry lead to a reduced number of observations for these variables. Source: Own calculations based on the Swiss Business Census ("BFS Betriebszählung”)

\begin{tabular}{|c|c|c|c|c|c|c|}
\hline Variable & Min. & Median & Mean & SD & Max. & Obs. \\
\hline \multicolumn{7}{|c|}{ I. All establishments } \\
\hline Size 2001 & 0.27 & 2.65 & 8.80 & 39.91 & $5,333.06$ & 262,032 \\
\hline Size 2005 & 0.28 & 2.62 & 8.78 & 40.42 & $5,825.10$ & 262,032 \\
\hline Age4 & 0.00 & 0.00 & 0.18 & 0.38 & 1.00 & 262,032 \\
\hline Age7 & 0.00 & 0.00 & 0.13 & 0.34 & 1.00 & 262,032 \\
\hline Age10 & 0.00 & 1.00 & 0.69 & 0.46 & 1.00 & 262,032 \\
\hline$H Q$ & 0.00 & 1.00 & 0.89 & 0.32 & 1.00 & 262,032 \\
\hline Foreign Capital & 0.00 & 0.00 & 0.02 & 0.14 & 1.00 & 262,032 \\
\hline Export Industry & 0.00 & 1.00 & 0.63 & 0.48 & 1.00 & 262,032 \\
\hline$A$ & 0.00 & 0.00 & 0.02 & 0.14 & 1.00 & 262,032 \\
\hline \multicolumn{7}{|c|}{ II. Acquired establishments $(A=1)$} \\
\hline Size 2001 & 0.27 & 5.93 & 21.75 & 63.99 & $1,542.60$ & 5,389 \\
\hline Size 2005 & 0.28 & 5.31 & 18.52 & 53.47 & 862.51 & 5,389 \\
\hline Age4 & 0.00 & 0.00 & 0.16 & 0.36 & 1.00 & 5,389 \\
\hline Age7 & 0.00 & 0.00 & 0.13 & 0.34 & 1.00 & 5,389 \\
\hline Age10 & 0.00 & 1.00 & 0.71 & 0.35 & 1.00 & 5,389 \\
\hline$H Q$ & 0.00 & 0.00 & 0.34 & 0.47 & 1.00 & 5,389 \\
\hline Foreign Capital & 0.00 & 0.00 & 0.04 & 0.21 & 1.00 & 5,389 \\
\hline Export Industry & 0.00 & 1.00 & 0.71 & 0.46 & 1.00 & 5,389 \\
\hline$A$ & 1.00 & 1.00 & 1.00 & 0.00 & 1.00 & 5,389 \\
\hline Acquirer Size & 0.27 & 207.24 & $4,057.17$ & $9,574.91$ & $29,666.63$ & 2,850 \\
\hline Integration Size & 0.27 & 92.08 & $1,786.58$ & $3,789.35$ & $13,888.08$ & 5,389 \\
\hline Related Industry & 0.00 & 1.00 & 0.63 & 0.48 & 1.00 & 2,850 \\
\hline
\end{tabular}

establishment in 2001. It ranges from 0.27 to 29,666.63 full-time equivalent employees, with 9,574.91 being the average. Related Industry equals 1 if the headquarters establishment of the acquiring firm operates in the same industry in 2001 as the acquired establishment. In our data set, $63 \%$ of all acquired establishments were acquired by a firm operating in a related industry.

Table 2 presents the total number of establishments in 2001, the number of establishments acquired between 2001 and 2005, and the acquisition rate for the manufacturing sector, split up by individual industries at the two-digit level. Table 3 does the same for the services sector. We define the acquisition rate as the number of establishments that are acquired from 2001 to 2005 divided by the total number of establishments in 2001.

In the manufacturing sector, 382 establishments out of 43,071 establishments were acquired, leading to an acquisition rate of $0.89 \%$. The highest number and also the highest rate of acquisition can be found in the industries for food products and beverages and chemicals. In the services sector, 5,007 out of 305,410 establishments were acquired, leading to an acquisition rate of $1.64 \%$, almost twice as much as in the manufacturing sector. Here, the highest acquisition rates can be found in the industries for post and telecommunications, banks, and insurance companies. Retail trade is the industry with the highest number of acquired establishments, however. In sum, Switzerland had 348,481 establishments in 2001, of which 5,389 were newly acquired by another firm between 2001 and 2005 .

Figure 1 shows the frequency distribution of the relative deal size, divided into four acquirer size groups. A general observation is that most acquiring firms acquire targets which are in sum smaller than themselves (relative deal size smaller than one). Still, patterns are different depending on the size group the 
Table 2 Firm establishment acquisitions in the manufacturing sector

\begin{tabular}{|c|c|c|c|c|}
\hline \multicolumn{2}{|c|}{ Industry } & \multirow{2}{*}{$\frac{\text { Establishments }}{3,188}$} & \multirow{2}{*}{$\frac{\text { Acquisitions }}{107}$} & \multirow{2}{*}{$\frac{\%}{3.36}$} \\
\hline 15 & Manufacture of food products and beverages & & & \\
\hline 16 & Manufacture of tobacco products & 18 & 0 & 0.00 \\
\hline 17 & Manufacture of textiles and textile products & 766 & 4 & 0.52 \\
\hline 18 & Manufacture of wearing apparel & 983 & 19 & 1.93 \\
\hline 19 & Manufacture of luggage, handbags, and saddlery & 309 & 0 & 0.00 \\
\hline 20 & Manufacture of wood and of products of wood & 6,578 & 13 & 0.20 \\
\hline 21 & Manufacture of pulp, paper, and paper products & 251 & 3 & 1.20 \\
\hline 22 & Publishing, printing, and reproduction of recorded media & 4,697 & 30 & 0.64 \\
\hline 23 & Manufacture of coke and refined petroleum products & 11 & 0 & 0.00 \\
\hline 24 & Manufacture of chemicals and chemical products & 1,143 & 36 & 3.15 \\
\hline 25 & Manufacture of rubber and plastic products & 894 & 6 & 0.67 \\
\hline 26 & Manufacture of other non-metallic mineral prod. & 1,521 & 32 & 2.10 \\
\hline 27 & Manufacture of basic metals & 296 & 5 & 1.69 \\
\hline 28 & Manufacture of fabricated metal products & 8,253 & 27 & 0.33 \\
\hline 29 & Manufacture of machinery and equipment n.e.c. & 3,689 & 32 & 0.87 \\
\hline 30 & Manufacture of office machinery & 145 & 0 & 0.00 \\
\hline 31 & Manufacture of electrical machinery & 1,142 & 13 & 1.14 \\
\hline 32 & Manufacture of radio and television & 689 & 8 & 1.16 \\
\hline 33 & Manufacture of medical and optical instruments & 3,552 & 29 & 0.82 \\
\hline 34 & Manufacture of motor vehicles and trailers & 195 & 1 & 0.51 \\
\hline 35 & Manufacture of other transport equipment & 424 & 3 & 0.71 \\
\hline 36 & Manufacture of furniture, jewelry, and toys & 3,970 & 10 & 0.25 \\
\hline 37 & Recycling & 357 & 4 & 1.12 \\
\hline \multicolumn{2}{|c|}{ All manufacturing industries } & 43,071 & 382 & 0.89 \\
\hline
\end{tabular}

This table splits up the sample of establishments operating in the Swiss manufacturing sector into different industries at the two-digit level, following the NOGA 2002 industry classification used by the Swiss Federal Statistical Office. For each industry, it then shows the number of establishments in 2001, the number of acquisitions that took place between 2001 and 2005 , and the resulting percentage of acquired establishments. Source: Own calculations based on the Swiss Business Census ("BFS Betriebszählung")

acquirer belongs to. While more than $60 \%$ of large acquiring firms acquire targets which are in sum smaller than $25 \%$ of their initial own size, the distribution broadens considerably for smaller acquirers: many micro-acquirers also acquire targets which have in sum up to 50,75 , or $100 \%$ of their own size. A few targets are even larger than the acquirers themselves. One possible explanation is a better availability of relevant targets in this size group.

\section{Empirical model}

Our empirical model is an OLS specification similar to that of Brown and Medoff (1988) and McGuckin and Nguyen (2001). In its main version, it takes the form

$$
\begin{aligned}
& \ln \left(\frac{\text { Size } 2005}{\text { Size 2001 }}\right)=\beta_{0}+\beta_{1} A+\beta_{2} \ln (\text { Size 2001) } \\
& +\beta_{3} \ln (\text { Size } 2001)^{2}+\beta_{4} \text { Age7 } \\
& +\beta_{5} \text { Age } 10+\beta_{6} H Q+\beta_{7} \text { Foreign Capital } \\
& +\beta_{8} \text { Export Industry }+\beta_{9} A \\
& \times \ln (\text { Acquirer Size })+\beta_{10} A \\
& \times \ln (\text { Integration Size })+\beta_{11} A \times A \text { ge } 7 \\
& +\beta_{12} A \times \text { Age } 10+\beta_{13} A \times H Q \\
& +\beta_{14} A \times \text { Foreign Capital } \\
& +\beta_{15} A \times \text { Export Industry }+\beta_{16} A \\
& \times \text { Related Industry } \\
& +\sum_{d=1}^{26} \beta_{17, d} \text { Industry }_{d} \\
& +\sum_{g=1}^{7} \beta_{18, g} \text { Region }_{g}+\epsilon
\end{aligned}
$$


Table 3 Firm establishment acquisitions in the services sector

This table splits up the sample of establishments operating in the Swiss services sector into different industries at the two-digit level, following the NOGA 2002 industry classification used by the Swiss Federal Statistical Office. For each industry, it then shows the number of establishments in 2001, the number of acquisitions that took place between 2001 and 2005 , and the resulting percentage of acquired establishments. Note that missing industry codes in the series of numbers either relate to public activities and thus are excluded (75, public administration and defense) or are not defined (all others, e.g., 42, 43). Source: Own calculations based on the Swiss Business Census ("BFS Betriebszählung")

\begin{tabular}{|c|c|c|c|c|}
\hline \multicolumn{2}{|c|}{ Industry } & \multirow{2}{*}{$\frac{\text { Establishments }}{453}$} & \multirow{2}{*}{$\frac{\text { Acquisitions }}{19}$} & \multirow{2}{*}{$\frac{\%}{4.19}$} \\
\hline 40 & Electricity, gas, steam, and hot water supply & & & \\
\hline 41 & Collection, purification, and distribution of water & 29 & 0 & 0.00 \\
\hline 45 & Construction & 36,108 & 162 & 0.45 \\
\hline 50 & Sale, maintenance, and repair of motor vehicles & 15,308 & 138 & 0.90 \\
\hline 51 & Wholesale trade and commission trade & 20,877 & 249 & 1.19 \\
\hline 52 & Retail trade and repair of household goods & 46,453 & 1,103 & 2.37 \\
\hline 55 & Hotels and restaurants & 26,974 & 676 & 2.51 \\
\hline 60 & Land transport and transport via pipelines & 8,579 & 89 & 1.04 \\
\hline 61 & Water transport & 102 & 0 & 0.00 \\
\hline 62 & Air transport & 240 & 6 & 2.50 \\
\hline 63 & Supporting and auxiliary transport activities & 3,996 & 183 & 4.58 \\
\hline 64 & Post and telecommunications & 1,170 & 188 & 16.07 \\
\hline 65 & Monetary intermediation & 3,951 & 488 & 12.35 \\
\hline 66 & Insurance (except compulsory social security) & 2,823 & 290 & 10.27 \\
\hline 67 & Activities auxiliary to financial intermediation & 3,718 & 65 & 1.75 \\
\hline 70 & Real estate activities & 4,480 & 22 & 0.49 \\
\hline 71 & Renting of machinery and equipment & 1,012 & 19 & 1.88 \\
\hline 72 & Computer and related activities & 11,519 & 39 & 0.34 \\
\hline 73 & Research and development & 497 & 5 & 1.01 \\
\hline 74 & Other business activities & 64,983 & 670 & 1.03 \\
\hline 80 & Education & 4,913 & 37 & 0.75 \\
\hline 85 & Health, veterinary, and social work & 23,016 & 283 & 1.23 \\
\hline 90 & Sewage and refuse disposal, sanitation & 468 & 8 & 1.71 \\
\hline 91 & Activities of membership organizations n.e.c. & 3,667 & 135 & 3.68 \\
\hline 92 & Recreational, cultural, and sporting activities & 6,014 & 36 & 0.60 \\
\hline 93 & Other service activities & 14,060 & 97 & 0.69 \\
\hline \multicolumn{2}{|c|}{ All services industries } & 305,410 & 5,007 & 1.64 \\
\hline
\end{tabular}

where the dependent variable reflects the growth of an establishment in terms of employment from 2001 to 2005: We divide the size of an establishment in 2005 by the size of that establishment in 2001, with size measured by the number of full-time equivalent employees. Then, the logarithm of the resulting expression is taken in order to get an approximate percentage effect.

As explanatory variables we have, first of all, $A$, which is our dummy denoting the acquisition status of an establishment. $A$ equals 1 if an establishment was acquired between 2001 and 2005, and zero otherwise. Size 2001 is the number of full-time equivalent employees of an establishment in 2001. Here we take the natural logarithm of this value since we want to talk about growth rates and also include the square of the logarithm in order to take non-monotonic behavior into account. Next, we include our age dummies, Age 7 and Age10. Age4, which equals 1 for the youngest establishments in this analysis, is used as a reference variable and thus is not included in Eq. (1). We also include our headquarters dummy, $H Q$, our dummy for foreign capital ownership, Foreign Capital, and our dummy for export-oriented industries, Export Industry.

In addition to these individual variables, eight other variables are included in interaction with $A$, the acquisition status variable of an establishment. $A \times$ $\ln$ (Integration Size $)$ is an interaction with the integration size, and $A \times \ln ($ Acquirer Size $)$ is an interaction with the acquirer size. These two interaction terms are used to relate the internal growth of an acquired establishment to the size differential between its acquirer and the total size of all of the acquisitions 
I. Micro acquirers

(0 to 9 full-time equivalent employees)

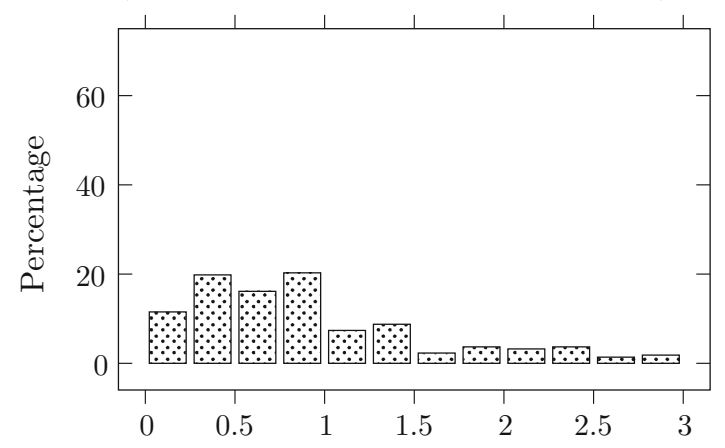

III. Medium acquirers

(50 to 249 full-time equivalent employees)

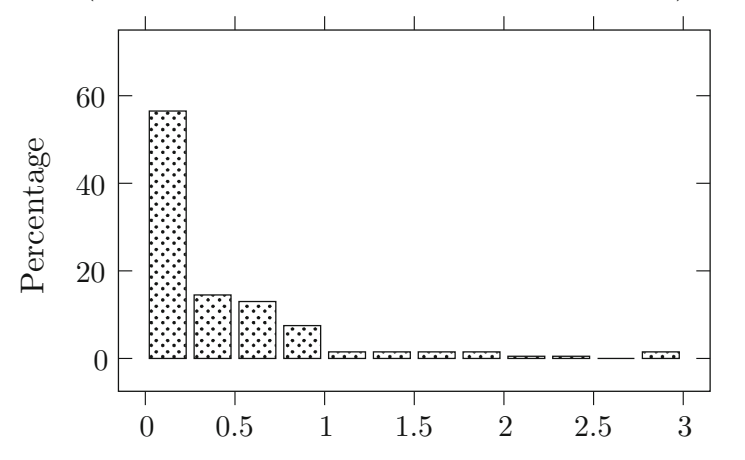

II. Small acquirers

(10 to 49 full-time equivalent employees)

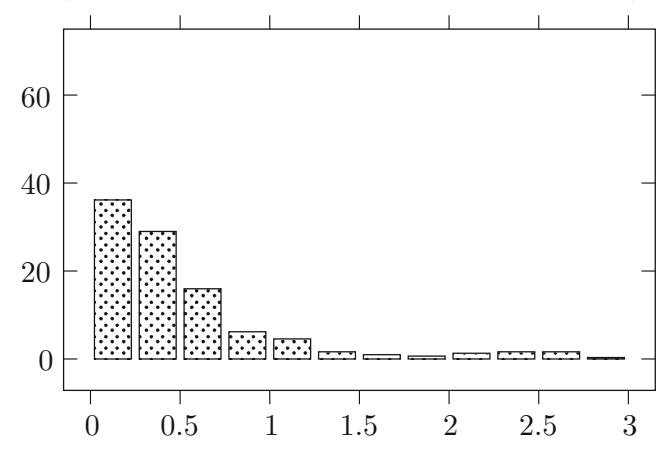

IV. Large acquirers

(250 or more full-time equivalent employees)

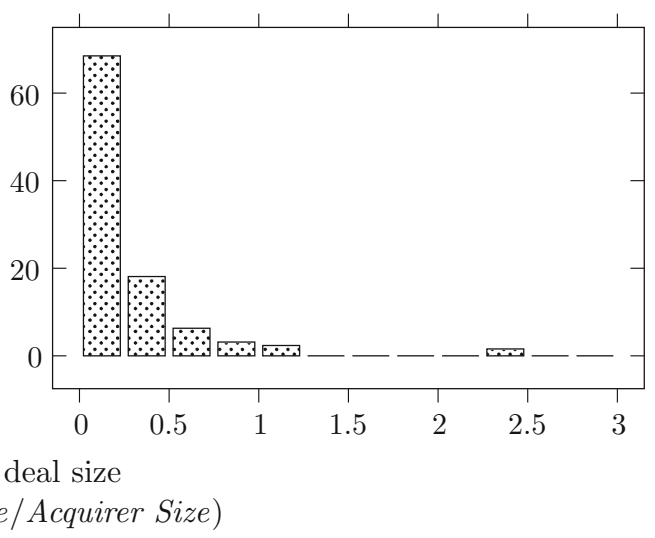

Fig. 1 Frequency distribution of relative deal size (by acquirer size). This figure splits up the sample of acquiring firms into four size groups, determined by their rounded number of full-time equivalent employees: micro-, small, medium, and large acquirers. Within each group, it then shows the frequency distribution of the acquirers' relative deal size, which is defined as the Integration Size of 2001 to 2005 divided by the Acquirer Size in 2001. It turns out, for example, that among large acquirers, $68.5 \%$ only acquire and integrate firm establishments

that this acquirer needs to integrate. Furthermore, interactions of A with Age7, Age10, HQ, Foreign Capital, Export Industry, and Related Industry are included. We also include 26 industry and 7 greater region dummies which equal 1 if an establishment operates in a certain industry or region and zero otherwise.

We estimate four models. As a start, model (1) is a restricted estimation without interaction terms in order to identify an overall effect of being acquired, $A=1$, on establishment growth in terms of employment. Model (2) is our main model and includes all interaction terms. Finally, there are two estimations which sum up to less than $25 \%$ of their initial own size (first bar in the chart on the bottom right). Almost no firm in that size group acquires establishments larger than her own size, i.e., with a relative deal size larger than one. Patterns in smaller size groups are similar, but way less pronounced. Note that only acquirers that started operating before September 2001 and with a relative deal size below 3 are considered. Source: Own calculations based on the Swiss Business Census ("BFS Betriebszählung”)

with a restricted sample. Model (3) only includes firms from the manufacturing sector, and model (4) only includes firms from the services sector. These allow us to address sectoral differences.

Before we present the results, two limitations of our approach should be noted. First, it is important to keep in mind that we interpret a special part of the sample. To calculate growth rates, we restrict our analysis to establishments which exist in both years of observation, 2001 and 2005. Small firms with slow or negative growth might be more likely to close than large firms with these characteristics, i.e., disappear from the sample in 2005. We thus might have a sample 
selection which biases the growth of small firms upward, because the worst performing ones drop out.

Second, a general concern with the present type of study is endogeneity. Our estimates are consistent if $A$ is not correlated with the error term, that is, if it is an exogenous variable. This assumption might be invalid. Previous studies have mostly ignored this issue. Only McGuckin and Nguyen (2001) provide a solution, using an instrumental variable estimation with relative plant productivity growth as an instrument for their equivalent of our $A$ variable. In Sect. 6, we suggest a different but related robustness check by looking at a subsample of "complete multi-establishment mergers" only. For these mergers, it is particularly reasonable to assume that the takeover of an individual establishment is exogenous, since merger decisions will typically be related to the advantages of the overall package the target is perceived to come with.

\section{Results and discussion}

\subsection{Establishment growth and size and age}

Table 4 presents our estimates for Eq. (1) and its modifications. ${ }^{5}$ A first result contributes to an ongoing debate on the growth of firms and firm establishments in general. We find that establishment growth decreases with establishment size and establishment age (at a decreasing rate) (Result 1). Throughout all regressions, we find negative coefficients that are statistically significant for the size of an establishment in 2001, $\ln ($ Size 2001). Furthermore, the coefficients for $\ln (\text { Size 2001 })^{2}$ turn out to be positive, indicating a decreasing negative impact of size on growth for larger establishments. Our coefficients for the establishment age dummies, Age7 and Age10, suggest the

\footnotetext{
${ }^{5}$ We thank an anonymous referee for pointing out that providing standard errors and related significance levels might actually not be appropriate when evaluating a full sample, depending on the type of research question. While it is true that here regression coefficients describe all available data and not just a sample in the usual sense, we take the view that our data should be seen as one possible realization of reality out of many potential realizations. Thus, in order to be able to draw conclusions about the mechanisms underlying this observed reality (our research objective), we believe that it is still appropriate to provide significance levels and related interpretations in the following. A more detailed discussion on this matter can be found, for example, in Berk et al. (1995).
}

same type of relationship between growth and age. For establishments in Switzerland, we can thus reject Gibrat's law of proportionate growth (which states that growth is independent of size, see Gibrat (1931) and Sutton (1997)). By contrast, our results confirm more recent studies that find an inverse relationship between growth and size or age (Dunne et al. 1989; Blonigen and Tomlin 2001). An explanation for the relationship is the theory of learning over time (Jovanovic 1982). Note, however, that establishment growth is different from total firm growth. Total firm growth can be decomposed into internal (establishment) growth and external growth through mergers and acquisitions. While our results do not contradict studies that find an inverse relationship between growth and size or age for firms so far (Hall 1987; Evans 1987a, b; Dunne and Hughes 1994; Harhoff et al. 1998), taking external growth into account might still do so, since we found that mergers and acquisitions are more prevalent among large firms. For example, Geroski and Gugler (2004) find Gibrat's law to hold for large and mature companies and confirm simultaneously an inverse relationship for small and young ones. We leave this point open to further research.

\subsection{The role of relative deal size}

Looking at the coefficient for $A$ in regression (1), we find that, overall, acquired establishments grow less rapidly than other establishments (Result 2). Such an adverse effect of acquisitions on growth is in line with Conyon et al. (2002), Gugler and Yurtoglu (2004), Bhagat et al. (1990), and Lichtenberg and Siegel (1990) as outlined above. However, this finding hides some important heterogeneity in the data. Notably, when including interaction terms with $A$ in regression (2), the baseline effect of $A$ becomes positive, while the interaction terms tend to pick up the difference. These interaction terms will thus be discussed in the following.

As a main result, we find that the larger the acquiring firm is compared to the combined size of the establishments to be integrated, the stronger the establishments grow following an acquisition (Result 3). From the positive coefficients for $A \times \ln ($ Acquirer Size $)$, i.e., the interaction of acquisition status with acquirer size, we can draw the following conclusion: Establishments that were acquired by larger acquiring firms grew more rapidly than establishments that were acquired 
Table 4 Employment growth regression estimates

\begin{tabular}{|c|c|c|c|c|}
\hline \multirow[t]{2}{*}{ Independent variable } & \multicolumn{4}{|c|}{ Dependent variable: In (Size 2005 / Size 2001) } \\
\hline & $\begin{array}{l}\text { (1) } \\
\text { All industries }\end{array}$ & $\begin{array}{l}\text { (2) } \\
\text { All industries }\end{array}$ & $\begin{array}{l}\text { (3) } \\
\text { Manufacturing }\end{array}$ & $\begin{array}{l}(4) \\
\text { Services }\end{array}$ \\
\hline $\ln ($ Size 2001) & $\begin{array}{l}-0.1704 * * * \\
(0.002)\end{array}$ & $\begin{array}{l}-0.1708 * * * \\
(0.002)\end{array}$ & $\begin{array}{l}-0.1191 * * * \\
(0.005)\end{array}$ & $\begin{array}{l}-0.1814 * * * \\
(0.002)\end{array}$ \\
\hline $\ln (\text { Size } 2001)^{2}$ & $\begin{array}{l}0.0273 * * * \\
(0.001)\end{array}$ & $\begin{array}{l}0.0276^{* * *} \\
(0.001)\end{array}$ & $\begin{array}{l}0.0176^{* * * *} \\
(0.001)\end{array}$ & $\begin{array}{l}0.0302 * * * \\
(0.001)\end{array}$ \\
\hline Age 7 & $\begin{array}{l}-0.0437 * * * \\
(0.004)\end{array}$ & $\begin{array}{l}-0.0432 * * * \\
(0.004)\end{array}$ & $\begin{array}{l}-0.0615^{* * *} \\
(0.010)\end{array}$ & $\begin{array}{l}-0.0407 * * * \\
(0.004)\end{array}$ \\
\hline Age10 & $\begin{array}{l}-0.0562 * * * \\
(0.003)\end{array}$ & $\begin{array}{l}-0.0558 * * * \\
(0.003)\end{array}$ & $\begin{array}{l}-0.0924 * * * \\
(0.008)\end{array}$ & $\begin{array}{l}-0.0509 * * * \\
(0.003)\end{array}$ \\
\hline$H Q$ & $\begin{array}{l}-0.0412 * * * \\
(0.003)\end{array}$ & $\begin{array}{l}-0.0411 * * * \\
(0.004)\end{array}$ & $\begin{array}{l}-0.0073 \\
(0.013)\end{array}$ & $\begin{array}{l}-0.0443 * * * \\
(0.004)\end{array}$ \\
\hline Foreign Capital & $\begin{array}{l}0.0460 * * * \\
(0.007)\end{array}$ & $\begin{array}{l}0.0449 * * * \\
(0.007)\end{array}$ & $\begin{array}{l}0.0047 \\
(0.017)\end{array}$ & $\begin{array}{l}0.0538 * * * \\
(0.008)\end{array}$ \\
\hline Export Industry & $\begin{array}{l}-0.1211^{* * *} \\
(0.029)\end{array}$ & $\begin{array}{l}-0.1151^{* * *} \\
(0.029)\end{array}$ & $\begin{array}{l}-0.0028 \\
(0.012)\end{array}$ & $\begin{array}{l}-0.1597 * * * \\
(0.047)\end{array}$ \\
\hline$A$ & $\begin{array}{l}-0.0342 * * * \\
(0.007)\end{array}$ & $\begin{array}{l}0.1636^{* * *} \\
(0.037)\end{array}$ & $\begin{array}{l}0.0178 \\
(0.198)\end{array}$ & $\begin{array}{l}0.1647 * * * \\
(0.038)\end{array}$ \\
\hline$A \times \ln ($ Acquirer Size $)$ & & $\begin{array}{l}0.0300^{* * *} \\
(0.004)\end{array}$ & $\begin{array}{l}0.0146 \\
(0.020)\end{array}$ & $\begin{array}{l}0.0310^{* * *} \\
(0.005)\end{array}$ \\
\hline$A \times \ln ($ Integration Size $)$ & & $\begin{array}{l}-0.0468 * * * \\
(0.004)\end{array}$ & $\begin{array}{l}-0.0417 * * \\
(0.017)\end{array}$ & $\begin{array}{l}-0.0485^{* * *} \\
(0.004)\end{array}$ \\
\hline$A \times A g e 7$ & & $\begin{array}{l}-0.0272 \\
(0.025)\end{array}$ & $\begin{array}{l}-0.3311^{* *} \\
(0.134)\end{array}$ & $\begin{array}{l}-0.0180 \\
(0.026)\end{array}$ \\
\hline$A \times A g e 10$ & & $\begin{array}{l}-0.0259 \\
(0.019)\end{array}$ & $\begin{array}{l}-0.0089 \\
(0.093)\end{array}$ & $\begin{array}{l}-0.0266 \\
(0.020)\end{array}$ \\
\hline$A \times H Q$ & & $\begin{array}{l}-0.0332 * \\
(0.017)\end{array}$ & $\begin{array}{l}0.0501 \\
(0.062)\end{array}$ & $\begin{array}{l}-0.0304 * \\
(0.018)\end{array}$ \\
\hline$A \times$ Foreign Capital & & $\begin{array}{l}0.0003 \\
(0.034)\end{array}$ & $\begin{array}{l}0.2957 * * * \\
(0.110)\end{array}$ & $\begin{array}{l}-0.0357 \\
(0.036)\end{array}$ \\
\hline$A \times$ Export Industry & & $\begin{array}{l}-0.1051 * * * \\
(0.016)\end{array}$ & $\begin{array}{l}-0.0452 \\
(0.137)\end{array}$ & $\begin{array}{l}-0.0954 * * * \\
(0.016)\end{array}$ \\
\hline$A \times$ Related Industry & & $\begin{array}{l}-0.0667 * * * \\
(0.020)\end{array}$ & $\begin{array}{l}-0.1158 \\
(0.073)\end{array}$ & $\begin{array}{l}-0.0649 * * * \\
(0.022)\end{array}$ \\
\hline Constant & $\begin{array}{l}0.3339 * * * \\
(0.028)\end{array}$ & $\begin{array}{l}0.3273 * * * \\
(0.028)\end{array}$ & $\begin{array}{l}0.1649 * * * \\
(0.017)\end{array}$ & $\begin{array}{l}0.3312^{* * * *} \\
(0.028)\end{array}$ \\
\hline Industry dummies & Yes & Yes & Yes & Yes \\
\hline Region dummies & Yes & Yes & Yes & Yes \\
\hline Observations & 262,032 & 262,032 & 33,457 & 228,575 \\
\hline$R^{2}$ & 0.047 & 0.048 & 0.039 & 0.049 \\
\hline
\end{tabular}

Standard errors in parentheses. Only surviving establishments are considered. To account for cases where the acquirer did not exist in 2001 and values for Acquirer Size and Related Industry are unavailable, missing dummies are included. Source: Own calculations based on the Swiss Business Census ("BFS

Betriebszählung")

$* * * p<0.01 ; * * p<0.05$;

* $p<0.1$ establishments' acquirer, we can conclude that establishments that were acquired by acquiring firms that have to integrate a large combined size of establishments grew less rapidly than establishments with 
acquirers of the opposite type. In sum, and as a central result, the relative deal size, defined as the size differential between the acquiring firm and the total integration size, matters for the internal growth of an acquired establishment: those establishments profit which are acquired by a firm that is considerably larger than their own size plus the size of the other establishments the firm acquired.

Our findings may well be explained by financial constraints through market imperfections (e.g., limited liability and moral hazard risk). Investment possibilities of firms depend on their internal resources. If these resources are exploited for external firm growth (i.e., through acquisitions), there only remains a low potential for internal growth through hiring additional employees. Limited internal resources may also include, for example, managerial capacities, which are exhausted in the course of new acquisitions. Hiring tasks are delayed. As a result, a high relative deal size should lead to lower internal employment growth in the acquired establishments.

Looking at the case where $\ln$ (Acquirer Size) equals $\ln$ (Integration Size), that is, a firm doubles its size through acquisitions, there is still an adverse effect on growth. The realization of synergy effects in the form of rationalizing overlapping employee positions is a reasonable explanation. In the services sector, the effect of relative deal size becomes positive as soon as $\ln$ (Integration Size) is at least $36 \%$ smaller than $\ln$ (Acquirer Size). In the manufacturing sector, the respective number is $65 \% .^{6}$ This might especially represent the case where mature firms buy smaller highly innovative firms with few overlapping functions but strong growth potentials.

\subsection{Further results}

In addition to the previous results, we observe important industry-specific differences in the relationship between mergers and acquisitions and employment growth. First, compared to other industries,

\footnotetext{
${ }^{6}$ For calculating these numbers, note that in the services sector, the total effect becomes positive when $0.0310 \times \ln ($ Acquirer Size $)+$ $(-0.0485) \times \ln ($ Integration Size $)>0$ or $(\ln ($ Acquirer Size $)-$ $\ln ($ Integration Size $)) / \ln ($ Acquirer Size $)>1-\frac{0.0310}{0.0485} \approx 0.36$. In the manufacturing sector, this corresponds to $(\ln ($ Acquirer Size $)-$ $\ln ($ Integration Size $)) / \ln ($ Acquirer Size $)>1-\frac{0.0146}{0.0417} \approx 0.65$.
}

mergers and acquisitions in export-oriented industries are associated with adverse effects on employment growth (Result 4). This result, in particular, holds for the services sector: the coefficient of $A \times$ Export Industry is negative and highly significant. For the manufacturing sector, the coefficient turns out to be negative, but insignificant. This result might be driven by the more competitive environment for firms in sectors with exposure to international trade (as modeled by Melitz 2003, for example). In the course of acquisitions, more synergy effects are realized than in environments with less competitive pressure. Recent empirical evidence on the existence of a relationship between the intensity of competition and mergers has been provided by Buehler et al. (2005), finding this relationship to be positive.

Second, mergers and acquisitions within related industries have adverse effects on employment growth (Result 5). As for the previous result, we find a negative and highly significant coefficient for $A \times$ Related Industry for the services sector and a negative but insignificant coefficient for the manufacturing sector. In this case, higher synergy effects might be realized not because of competitive pressure, but because of the greater possibilities of rationalization which firms obtain when merging with similar establishments. This is consistent with Conyon et al. (2002). Another explanation is the creation of market power allowing the merging firms to internalize their competitive externalities in the product market through reduced production.

It also turns out that headquarters of multi-establishment firms grow less rapidly than their other establishments (Result 6). In all regressions, the coefficient for $H Q$ is negative. It is highly significant for the regression that includes all industries, as well as for the services sector alone. A reason might be that auxiliary headquarters services (such as marketing or accounting) usually do not need to grow as rapidly as the full institutional unit when expanding production and services to serve additional customers. Surprisingly, however, the effect is statistically insignificant in the manufacturing sector alone.

Furthermore, acquired establishments with headquarters status, i.e., where $A \times H Q$ equals 1 , grow less rapidly than other acquired establishments (Result 7). This result is consistent with Bhagat et al. (1990) and Lichtenberg and Siegel (1990), who find that in particular white-collar worker and auxiliary plants 
are affected by layoffs following mergers and acquisitions. However, the coefficient in the regression with only the manufacturing sector is insignificant.

As a last result, we find that foreign-owned establishments grow more rapidly than establishments endowed with domestic capital only. Compared to Swiss establishments, the acquisition of foreignowned establishments is positively related to their growth in the manufacturing sector (Result 8). The coefficient for $A \times$ Foreign Capital is positive and highly significant for this sector. In all regressions, the coefficient for the Foreign Capital variable is positive. However, it is not statistically significant for the manufacturing sector alone. Thus, this result again especially holds for the services sector. An explanation might be that foreign-owned establishments benefit from technology transfer from their foreign owners. While increasing productivity, firms have high incentives to keep their employees: first, training staff in new technologies is costly, and second, technology spillover effects to competitors can be constrained (see, for example, Teece 1986; Görg and Strobl 2005, or Görg and Greenaway 2004).

\section{Complete multi-establishment mergers}

As indicated in Sect. 4, a concern with our regression model is the potential endogeneity of the acquisition variable $A$, which would lead to regression estimates that are not consistent. In particular, we think of omitted variables (or unobserved heterogeneity) as the channel for endogeneity. Omitted variables could be variables on relevant establishment characteristics, such as an indicator for the talent of an establishment's management. Talented management might be crucial for the growth of an establishment. At the same time, talented management in a target establishment might also be decisive for the acquisition status: acquirers might want to select specifically those establishments as a target, which have exceptional growth prospects thanks to their management. If this were true and if we cannot control for talent in our regression, $A$ would be correlated with the error term $\epsilon$ and our regression estimates would be inconsistent. In the example of talented management, the coefficient for $A$ would be biased upward.
A potential solution to this concern is an instrumental variable estimation. Unfortunately, an ideal instrumental variable for $A$ is typically not readily available for our kind of study. Most previous studies actually ignored this issue. However, a related possibility is to exclusively look at acquired establishments which are part of a "complete multi-establishment merger". We define such a merger as a standard merger which fulfills two additional conditions. First, the merger includes the takeover of at least one complete firm, that is, a firm with all of its establishments. Second, the target firm consists of at least four individual establishments. The underlying idea is to avoid cherry-picking with regard to the unobserved heterogeneity at the establishment level: For complete multi-establishment mergers, it might be more reasonable to assume that the takeover of an individual establishment is exogenous, since merger decisions will typically be related to the advantages of the overall package the target is perceived to come with. Note that concerning our definition of complete multiestablishment mergers, there is a trade-off. On the one hand, requiring a higher number of establishments to be part of the target makes the selection of a specific establishment more random. On the other hand, the observed subsample of acquired establishments shrinks with a more rigorous definition. In the end, requiring at least four establishments seems to be appropriate: out of 5,389 establishments that were acquired according to our standard merger definition, 271 establishments still fulfilled our additional requirements.

Table 5 presents the regression results for such complete multi-establishment mergers, where other mergers are excluded. As in model (1), model (5) does not include interaction terms. It turns out that the regression coefficient for $A$ has a somewhat higher magnitude, but is still negative and statistically significant, and thus broadly comparable to the coefficient in model (1). Estimation (6) includes all interaction terms as in estimation (2) above. There is almost no change in the coefficients for establishment size, age, headquarters status, or export orientation. The coefficients for the acquisition status and its interaction terms with size, however, now become insignificant. The same holds for the other interaction terms. Presumably, the reduced number of mergers 
Table 5 Supplementary regression estimates
Standard errors in

parentheses. Only surviving

establishments are

considered. To account for

cases where the acquirer did

not exist in 2001 and values

for Acquirer Size and

Related Industry are

unavailable, missing

dummies are included.

Acquired establishments

which are not part of a

merger with at least four

target establishments are

excluded from the sample in

estimations (5) and (6).

Furthermore, as Foreign

Capital is zero for all

establishments within the

remaining group of

acquired establishments, the

interaction term $A \times$

Foreign Capital has been

omitted in these regressions.

Source: Own calculations

based on the Swiss Business

Census ("BFS

Betriebszählung")

$* * * p<0.01$; ** $p<0.05$;

$* p<0.1$

\begin{tabular}{|c|c|c|}
\hline \multirow[t]{2}{*}{ Independent variable } & \multicolumn{2}{|c|}{ Dependent variable: ln (Size 2005 / Size 2001) } \\
\hline & $\begin{array}{l}\text { (5) } \\
\text { Complete multi- } \\
\text { establishment mergers }\end{array}$ & $\begin{array}{l}\text { (6) } \\
\text { Complete multi- } \\
\text { establishment mergers }\end{array}$ \\
\hline $\ln ($ Size 2001) & $\begin{array}{l}-0.1733^{* * *} \\
(0.002)\end{array}$ & $\begin{array}{l}-0.1733^{* *} \\
(0.002)\end{array}$ \\
\hline $\ln (\text { Size 2001) })^{2}$ & $\begin{array}{l}0.0294 * * * \\
(0.001)\end{array}$ & $\begin{array}{l}0.0294 * * * \\
(0.001)\end{array}$ \\
\hline Age 7 & $\begin{array}{l}-0.0428^{* * *} \\
(0.003)\end{array}$ & $\begin{array}{l}-0.0429^{* *} \\
(0.003)\end{array}$ \\
\hline Age10 & $\begin{array}{l}-0.0563 * * * \\
(0.003)\end{array}$ & $\begin{array}{l}-0.0563^{* *} \\
(0.003)\end{array}$ \\
\hline$H Q$ & $\begin{array}{l}-0.0410 * * * \\
(0.003)\end{array}$ & $\begin{array}{l}-0.0410^{* *} \\
(0.003)\end{array}$ \\
\hline Foreign Capital & $\begin{array}{l}0.0379 * * * \\
(0.007)\end{array}$ & $\begin{array}{l}0.0378^{* * *} \\
(0.007)\end{array}$ \\
\hline Export Industry & $\begin{array}{l}-0.1005^{* * *} \\
(0.029)\end{array}$ & $\begin{array}{l}-0.0996^{* *} \\
(0.029)\end{array}$ \\
\hline$A$ & $\begin{array}{l}-0.0523^{*} \\
(0.030)\end{array}$ & $\begin{array}{l}0.0009 \\
(0.287)\end{array}$ \\
\hline$A \times \ln ($ Acquirer Size $)$ & & $\begin{array}{l}0.0057 \\
(0.056)\end{array}$ \\
\hline$A \times \ln ($ Integration Size $)$ & & $\begin{array}{l}-0.0185 \\
(0.033)\end{array}$ \\
\hline$A \times A g e 7$ & & $\begin{array}{l}0.0936 \\
(0.114)\end{array}$ \\
\hline$A \times A g e 10$ & & $\begin{array}{l}-0.0646 \\
(0.074)\end{array}$ \\
\hline$A \times H Q$ & & $\begin{array}{l}0.0996 \\
(0.086)\end{array}$ \\
\hline$A \times$ Export Industry & & $\begin{array}{l}-0.1091 \\
(0.067)\end{array}$ \\
\hline$A \times$ Related Industry & & $\begin{array}{l}0.0097 \\
(0.045)\end{array}$ \\
\hline Constant & $\begin{array}{l}0.3119 * * * \\
(0.028)\end{array}$ & $\begin{array}{l}0.3109 * * * \\
(0.028)\end{array}$ \\
\hline Industry dummies & Yes & Yes \\
\hline Region dummies & Yes & Yes \\
\hline Observations & 256,914 & 256,914 \\
\hline$R^{2}$ & 0.046 & 0.046 \\
\hline
\end{tabular}

that we look at plays a major role. We obtain very similar results (which are available upon request) when changing the number of establishments that the target firm is required to consist of. Note again, however, that all these results have their own limitations, as they are based on a subsample of all the mergers in our data set. In particular, this smaller sample might at the same time only represent a very specific type of mergers, such as mergers aiming at the diversification of an acquirer's business. 


\section{Conclusion}

This paper started with raising the following questions: What determines the growth of firms and their establishments? Do small establishments grow more rapidly than large ones? And how is an establishment's growth affected by mergers and acquisitions?

Our study suggests that the relative size of a deal constitutes an important determinant for a newly acquired establishment's growth in terms of employees. In particular, we find that a larger size of the acquiring firm has a beneficial effect on employment growth, while a larger size of the acquired establishments has an adverse effect. This finding is new to the literature and several potential explanations are in line with it. One explanation is constraints on the financial resources of the acquiring firm: high acquisition costs restrict the potential of hiring additional employees, while with lower acquisition costs, hiring additional employees is comparatively unrestricted. Other explanations include market power effects and exhausted managerial capacities. Concerning the general determinants for an establishment's growth, we find that establishment growth decreases with its initial size and age. For our data on firm establishments in Switzerland, we can thus reject Gibrat's law of proportionate growth, stating that growth is uncorrelated with initial size. Our result holds at the aggregate level as well as when manufacturing and services sectors are evaluated separately. This study also investigated further potential growth determinants, such an establishment's headquarter status, its foreign ownership status, or the type of industry a firm establishment operates in.

Future research could further explore our key finding that the relative size of a deal is an important determinant for a newly acquired firm establishment's growth. In particular, the analysis of financial data could provide additional evidence on our suggestion that financing constraints are an explanation for our finding. The empirical literature would also benefit from complementary theoretical work that carves out the different motives for mergers and the individual effects these might have on a firm's employees.

Acknowledgments We thank Stefan Buehler, Simon Evenett, Christina Felfe, Klaus Gugler, Giovanni Mellace, Farzad Saidi, Philip Schuster, Conny Wunsch, two anonymous referees, as well as seminar participants at the University of St. Gallen, ETH Zurich, the Swiss IO Day 2010 (Bern), the IIOC 2011 (Boston), and the EEA-ESEM Congress 2011 (Oslo) for helpful comments. We also thank the Swiss Federal Statistical Office for providing their Business Census data through Contracts No. 08350 and 140146. Financial support from the Swiss National Science Foundation through Grants No. PP0011-114754 and PBSGP1-138787 is gratefully acknowledged.

\section{References}

Almus, M., \& Nerlinger, E. A. (2000). Testing Gibrat's Law for young firms: Empirical results for West Germany. Small Business Economics, 15(1), 1-12. doi:10.1023/A: 1026512005921.

Andrade, G., Mitchell, M., \& Stafford, E. (2001). New evidence and perspectives on mergers. Journal of Economic Perspectives, 15(2), 103-120. doi:10.1257/jep.15.2.103.

Audretsch, D. B., Klomp, L., Santarelli, E., \& Thurik, R. (2004). Gibrat's Law: Are the services different? Review of Industrial Organization, 24(3), 301-324. doi:10.1023/B: REIO.0000038273.50622.ec.

Berk, R. A., Western, B., \& Weiss, R. E. (1995). Statistical inference for apparent populations. Sociological Methodology, 25, 421-458. doi:10.2307/271073.

Bhagat, S., Shleifer, A., Vishny, R. W., Jarrel, G., \& Summers, L. (1990). Hostile takeovers in the 1980s: The Return to corporate specialization. brookings papers on economic activity. Microeconomics, 1990, 1-84. doi:10.2307/2534780.

Blonigen, B. A., \& Tomlin, K. S. (2001). Size and growth of Japanese plants in the United States. International Journal of Industrial Organization, 19(6), 931-952. doi:10.1016/ S0167-7187(99)00055-7.

Brown, C., \& Medoff, J. L. (1988). The impact of firm acquisitions on labor. In A. J. Auerbach (Ed.), Corporate takeovers: Causes and consequences. Chicago: University of Chicago Press.

Buehler, S., Kaiser, C., \& Jaeger, F. (2005). Competition policy and exit rates: Evidence from Switzerland. Contributions in Economic Analysis and Policy, 4(1), 1-28. doi:10.2202/ 1538-0645.1444.

Carpenter, R. E., \& Petersen, B. C. (2002). Is the growth of small firms constrained by internal finance? Review of Economics and Statistics, 84(2), 298-309. doi:10.1162/ 003465302317411541.

Conyon, M. J., Girma, S., Thompson, S., \& Wright, P. W. (2002). The impact of mergers and acquisitions on company employment in the United Kingdom. European Economic Review, 46(1), 31-49. doi:10.1016/S00142921(00)00086-6.

Daunfeldt, S.-O., \& Elert, N. (2013). When is Gibrat's Law a law? Small Business Economics, 41(1), 133-147. doi:10. 1007/s11187-011-9404-x.

Dunne, P., \& Hughes, A. (1994). Age, size, growth and survival: UK companies in the 1980s. Journal of Industrial Economics, 42(2), 115-140. doi:10.2307/2950485.

Dunne, T., Roberts, M. J., \& Samuelson, L. (1989). The growth and failure of U.S. manufacturing plants. Quarterly Journal of Economics, 104(4), 671-698. doi:10.2307/2937862.

Evans, D. S. (1987a). The relationship between firm growth, size, and age: Estimates for 100 manufacturing industries. 
Journal of Industrial Economics, 35(4), 567-581. doi:10. 2307/2098588.

Evans, D. S. (1987b). Tests of alternative theories of firm growth. Journal of Political Economy, 95(4), 657-674. doi:10.1086/261480.

Fotopoulos, G., \& Giotopoulos, I. (2010). Gibrat's Law and persistence of growth in Greek manufacturing. Small Business Economics, 35(2), 191-202. doi:10.1007/s11187008-9163-5.

Geroski, P., \& Gugler, K. (2004). Corporate growth convergence in Europe. Oxford Economic Papers, 56(4), 597-620. doi:10.1093/oep/gpf055.

Gibrat, R. (1931). Les inegalites economiques. Paris: Recueil sirey.

Green, M. B., \& Cromley, R. G. (1982). The horizontal merger: Its motives and spatial employment impacts. Economic Geography, 58(4), 358-370. doi:10.2307/143460.

Görg, H., \& Greenaway, D. (2004). Much ado about nothing? Do domestic firms really benefit from foreign direct investment? World Bank Research Observer, 19(2), 171-197. doi:10.1093/wbro/lkh019.

Görg, H., \& Strobl, E. (2005). Spillovers from foreign firms through worker mobility: An empirical investigation. Scandinavian Journal of Economics, 107(4), 693-709. doi:10.1111/j.1467-9442.2005.00427.x.

Gugler, K., \& Yurtoglu Burcin, B. (2004). The effects of mergers on company employment in the USA and Europe. International Journal of Industrial Organization, 22(4), 481-502. doi:10.1016/j.ijindorg.2003.12.003.

Hall, B. H. (1987). The relationship between firm size and firm growth in the US manufacturing sector. Journal of Industrial Economics, 35(4), 583-606. doi:10.2307/2098589.

Harhoff, D., Stahl, K., \& Woywode, M. (1998). Legal form, growth and exit of West German firms: Empirical results for manufacturing, construction, trade and service industries. Journal of Industrial Economics, 46(4), 453-488. doi:10.1111/1467-6451.00083.

Hoogstra, G. J., \& van Dijk, J. (2003). Explaining firm employment growth: Does location matter? Small Business Economics, 22(3-4), 179-192. doi:10.1023/B:SBEJ. 0000022218.66156.ac.

Jovanovic, B. (1982). Selection and the evolution of industry. Econometrica, 50(3), 649-670. doi:10.2307/1912606.

Lensink, R., van Steen, P., \& Sterken, E. (2005). Uncertainty and growth of the firm. Small Business Economics, 24(4), 381-391. doi:10.1007/s11187-005-7121-z.
Lichtenberg, F. R., \& Siegel, D. (1990). The effect of ownership changes on the employment and wages of central office and other personnel. Journal of Law and Economics, 33(2), 383-408. doi:10.1086/467210.

Lotti, F., Santarelli, E., \& Vivarelli, M. (2003). Does Gibrat's Law hold among young, small firms? Journal of Evolutionary Economics, 13(3), 213-235. doi:10.1007/s00191003-0153-0.

McGuckin, R. H., \& Nguyen, S. V. (2001). The impact of ownership changes: A view from labor markets. International Journal of Industrial Organization, 19(5), 739-762. doi:10.1016/S0167-7187(00)00092-8.

Melitz, M. J. (2003). The impact of trade on intra-industry reallocations and aggregate industry productivity. Econometrica, 71(6), 1695-1725. doi:10.1111/1468-0262. 00467.

Nunes, P. M., Gonçalves, M., \& Serrasqueiro, Z. (2013). The influence of age on SMEs' growth determinants: Empirical evidence. Small Business Economics, 40(2), 249-272. doi:10.1007/s11187-011-9363-2.

Oliviera, B., \& Fortunato, A. (2006). Firm growth and liquidity constraints: A dynamic analysis. Small Business Economics, 27(2-3), 139-156. doi:10.1007/s11187-006-0006-y.

Reid, G. C., \& Xu, Z. (2012). Generalising Gibrat: Using Chinese evidence founded on fieldwork. Small Business Economics, 39(4), 1017-1028. doi:10.1007/s11187-011-93383.

Robson, P. J. A., \& Bennett, R. J. (2000). SME growth: The relationship with business advice and external collaboration. Small Business Economics, 15(3), 193-208. doi:10. 1023/A:1008129012953.

Sutton, J. (1997). Gibrat's legacy. Journal of Economic Literature, 35(1), 40-59.

Swiss Federal Statistical Office. (2006). Betriebszählung 2005. Grundlagen und Methoden. Neuchâtel: Bundesamt für Statistik (BFS). http://www.bz.bfs.admin.ch/.

Teece, D. J. (1986). Profiting from Technological innovation: Implications for integration, collaboration, licensing and public policy. Research Policy, 15(6), 285-305. doi:10. 1016/0048-7333(86)90027-2.

Teruel-Carrizosa, M. (2010). Gibrat's Law and the learning process. Small Business Economics, 34(4), 355-373. doi:10.1007/s11187-008-9127-9.

Yasuda, T. (2005). Firm growth, size, age and behavior in Japanese manufacturing. Small Business Economics, 24(1), 1-15. doi:10.1007/s11187-005-7568-y. 